\title{
The Effectiveness of Physics Mobile Learning (PML) with HomboBatu theme to Improve the Ability of Diagram Representation and Critical Thinking of Senior High School Students
}

\section{Reza Dwi Saputra}

Universitas Negeri Yogyakarta, Indonesia, rezadwi873@gmail.com

\section{Heru Kuswanto}

Universitas Negeri Yogyakarta, Indonesia, herukus61@uny.ac.id

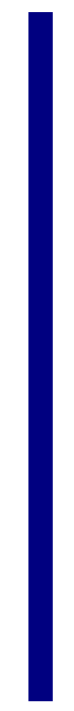

\begin{abstract}
This study aimed to determine the effectiveness of Physics Mobile Learning (PML) with HomboBatu theme smartphone Android-Assisted to improve the ability of diagram representation and critical thinking of students of Grade $\mathrm{X}$ in senior high school. The research type used was experimental research with pretestposttest control group design. The sampling technique selection used cluster random sampling. The subjects were 32 students of Grade X MIPA 4, SMAN 6 Yogyakarta as control class with learning treatment of Powerpoint media and 22 students of Grade X MIPA 7, SMAN 6 Yogyakarta as experimental class with learning treatment of PML smartphone Android-Assisted with BatuHombo theme. Test instruments consisted of pretest and posttest. Data analysis used was analysis of N-Gain and Hotteling's Trace multivariate test (MANOVA). The results showed that learning with PML-themed HomboBatu media was more effective in increasing the representation ability of $\mathrm{N}$-Gain diagrams by 0.78 in the high category. However, there was no significant difference in N-Gain scores in the experimental class and control class in improving critical thinking skills. This Physics Mobile Learning can be used by students or teachers to study Indonesian culture (Nias) for its learning media as well as for learning experiences that train the ability of diagram representation and critical thinking.
\end{abstract}

Keywords: physics mobile learning, HomboBatu, diagram representation, critical thinking, learning

\section{INTRODUCTION}

Ability of representation and critical thinking is a way to solve a problem in physics learning (Docktor\&Mestre, 2014). The use and selection of appropriate representation formats can improve students' performance and provide access to obtain knowledge that

Citation: Saputra, M. R. D., \& Kuswanto, H. (2019). The Effectiveness of Physics Mobile Learning (PML) with HomboBatu theme to Improve the Ability of Diagram Representation and Critical Thinking of Senior High School Students. International Journal of Instruction, 12(2), 471-490. https://doi.org/10.29333/iji.2019.12230a 
is more complete (Fredlund, Linder, Airey, \& Linder, 2014), making it easier for students to understand physical problems and also to provide guidance and instruction in solving physical problems (Docktor\&Mestre, 2014; Kohl \& Finkelstein, 2005; Tuminaro \& Redish, 2007). Students who are able to draw free body diagrams correctly are more able to accurately solve the Physics problem (Larkin \& Simon, 2009; Rosengrant, Van Heuvelen, \&Etkina, 2005). Diagram representation is needed by students in solving the physics problems because the characteristics of physics are explained visually, such as using a force diagram or motion diagrams.

Students' critical thinking ability becomes a necessity and a process of thinking for problem solving in everyday life (De Cock, 2012; Masek \& Yamin, 2011). Rusipal (2011) states that physics subjects can train students' critical thinking processes in problem solving. Research by Nurohman, Ashari, and Nurhidayati (2014), and by Pratama and Istiyono (2015) revealed that students' thinking ability has not been optimally developed through the process of Physics learning. This learning should focus on the idea that Physics is the type of learning that requires higher order thinking skills, such as the ability of diagram representation and critical thinking (Putra \&Sudarti, 2015).

Physics mobile learning is a learning medium previously developed by integrating the HomboBatu culture with Android and Physics subjects that is used as a new learning strategy and provides an interesting transformation experience (Saputra, 2018; Yáñez, Okada, \& Palau, 2015). Using mobile learning (Android) in the learning process can support higher learning through students' participation in the use of technology, especially using mobile learning in critical thinking processes (Mwest, 2013; Mccann, 2015). Moreover, PML facilitates the students' understanding with regard to the difficulty of physics material in the classroom such as in providing animation, simulation, and learning videos.

Physics mobile learning includes the ability of diagram representation and critical thinking, and it can be used by students to train and develop their abilities in diagram representation and critical thinking (Saputra, 2018). Chennamo, Ross, and Ertmer (2010: $283 \&$ 357) in their study also state that technology and integration of culture understanding support the learning process and are needed by students and that an authentic culture in learning facilitates students in obtaining better understanding in terms of language and culture, especially in improving their ability of diagram representation and critical thinking. Therefore, a research on implementation of PML with HomboBatu theme was conducted to improve the students' ability of diagram representation and critical thinking.

\section{LITERATURE REVIEW}

\section{Smartphone Android sebagai M-Learning}

Android is a modified Linux-based operating system that is a complete and free open source that has dominated the technology markets (Banks, 2014; Chao, 2012; Huda, 2013; Safaat, 2012). Android can be used as a mobile learning tool (Chao, 2012) which is flexible, wherever and whenever (Ally \& Prieto-Blázquez, 2014). Additionally, 
Kumar (2013) states that the advantages of using mobile learning in the learning process are: increased mobility; time saving; being environmentally friendly; and interactive.

Mobile learning provides possibilities for students to learn wherever and whenever (Poore, 2013: 144), supports the learning process of Physics, is an efficient learning medium, and facilitates conveyance of the materials or tools (Acedo, 2014; Kumar, 2013; Sarrab, Elgamel \& Aldabbas, 2013). Studies have found (Cavus \& Uzunboylu, 2009; Cobcroft, Towers, Smith, \&Bruns 2015) that mobile technology is able to support the involvement of students in creative, collaborative, critical, and communicative learning activities (Cobcroft et al., 2015).

\section{HomboBatu as learning resource}

HomboBatu (StoneJumping), a Culture from Nias Island, is from Bawomatatuo village, Teluk Dalam District. Siregar \& Syamsuddin (2015) states "The HomboBatu tradition or stone jumping is a unique local tradition and attracts the attention of the world, and the culture has lived hereditary in the middle of Nias Island people, North Sumatra, Indonesia."

Siregar and Syamsuddin (2015) in their research state that the integration of the HomboBatu tradition into media of character education provides positive characteristics, such as agility, maturity, courage, tenacity, fighting power, and heroism. The culture of HomboBatu (in Fig.1) can be used as a resource of learning on material of Newton's Law and Parabolic Motion.

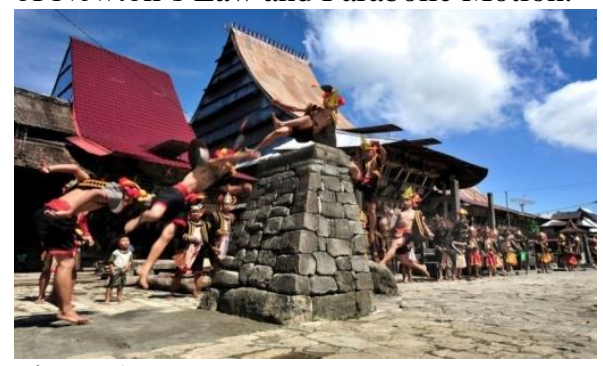

Figure 1

A. Young is Performing HomboBatu

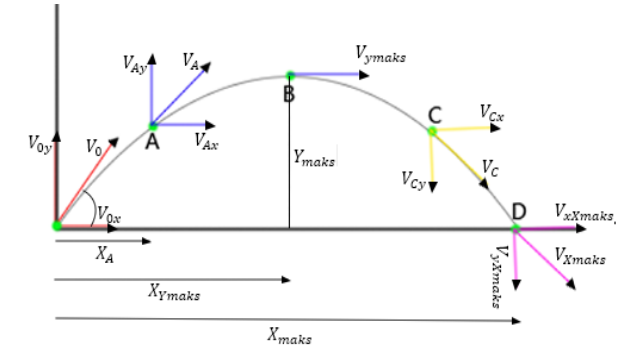

Figure 2

The Example of Parabolic Motion Analysis on HomboBatu

\section{Diagram Representation and Critical Thinking}

Frisch (2014) states that representation is the main point in Physics. The ability of representation is often used by experts / scientists to solve problems, but it is not yet being used by students in Physics learning (Gilbert \&Treagust, 2009). Representation ability is an important ability of students to solve the problem of Physics (Hubber, Tytler\& Haslam, 2010). Representation sometimes has a different meaning in an object (Schnotz, Baadte, Muller, \&Rasch, 2010).

Ainsworth (1999) divided representation into three functions: 1) improvement of other representations; 2) to provide an interpretation; 3 ) to construct a deeper understanding 
(Wong, Poo, Hock, \& Kang, 2011). Tms and Sirait (2016) provide explanation that various representations are used as an alternative instruction to teach Physics in order that it can facilitate the students in understanding the concepts and problems visually before they understand mathematical equations. Maries and Singh (2013) state that diagram representations are representation providing information on the situation of a system to solve the problems on the system. The free body diagram in the study by Ayesh, Qamhieh, Tit, and Abdelfattah (2010) is a multi-diagram representation that is defined as image representations in problems relating to force.

Critical thinking is a process when a person thinks deeply (Fisher, 2009; Glaser, 1941), analyzes (Fisher, 2001), assess, and evaluates (Abrami, Bernard, Borokhovski, Waddington, Wade \&Perrson, 2014) to find athought, an idea, or an assumption (Brookfield, 2012) which has rational reasons to solve a problem (De Cock, 2012; Masek\&Yamin, 2011; Stemberg, 1985) so as to obtain a logical conclusion (McGregor, 2007; Gambrill \& Gibss, 2009).

\section{METHOD}

\section{Research design}

This research study is an advanced experimental study with a pretest-posttest control group design (Sugiyono, 2016: 303). The observation of this research covers the control and experimental classes. Experimental class learning uses PML media. During the learning process, students use the Android smartphone as a tool to run the PML application that integrates HomboBatu culture while the control class uses Powerpoint media that does not integrate the HomboBatu culture. The learning process is carried out in the classroom three times in the subject of Newton's Law, both in experimental class and control class using the scientific approach and the model of Learning Discovery.

\section{Participants}

This research was conducted at SMANN 6 Yogyakarta with an experimental class sample (X MIPA 7) totaling 22 students and a control class (X MIPA 4) with a subject of 32 students. The sample selection was done randomly (cluster random sampling) from all class X of SMAN 6 Yogyakarta.

\section{Research Instrument}

The research instrument used in this study is those pre-posttest questions which are arranged based on indicators (Table 1) in the ability of diagram representation and critical thinking and that have been validated by experts and tested empirically. Empirical tests are analyzed with QUEST software. The questions tested consisted of 17 description questions made up of five questions regarding the ability of diagram representation and 12 questions of critical thinking skills. Question items are in the Infit Mean Square (MNSQ) range with a limit of $0.77-1.30$ and using INFIT $t$ with the item acceptance criteria is INFIT $\mathrm{t} \leq 2$. The results of the analysis can be seen in Fig. 3 . 


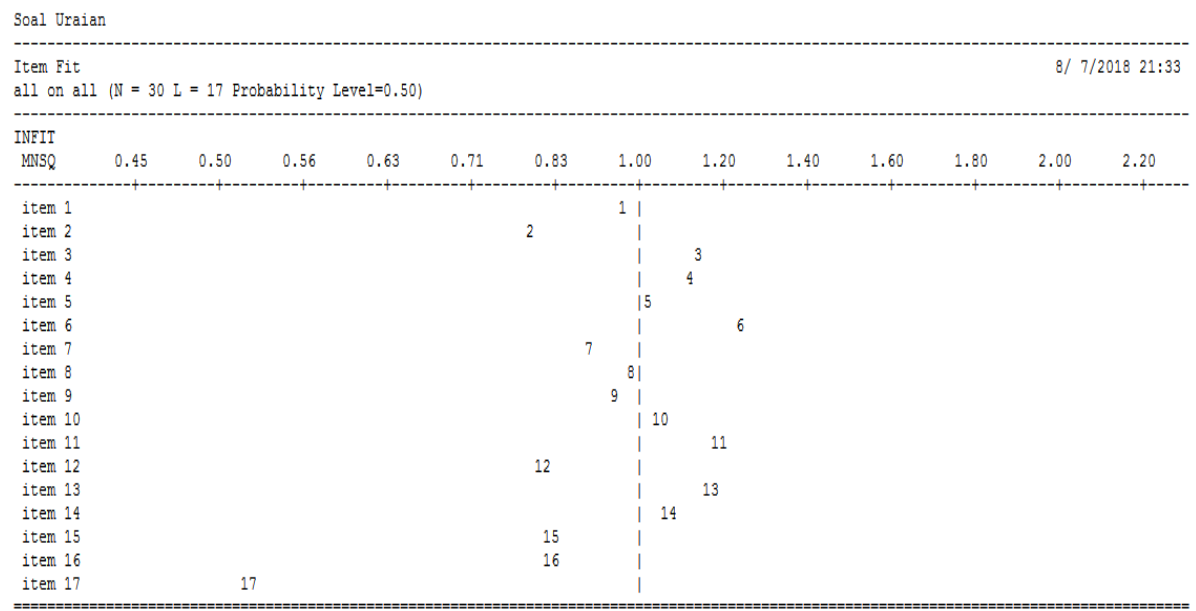

Figure 3

Analytical Results of Emperical Trial

The question consists of 17 questions which are divided into five diagram representation items (items 1-5) and critical thinking questions (items 6-17). The interpretation of the above analysis shows that only item number 17 (critical thinking question) has INFIT MNSQ $<0.77$, meaning that item number 17 is not suitable or fit with a PCM model or 1-PL model with an acceptable limit of 0.77 - 1, 30, so that only item number 17 cannot be used in field trials (experiments). The results of reliability obtained are 0.713 , with a reliable category based on the theory of Gliem and Gliem (2003). The pretest and posttest questions used in the study were only eight essay questions about the application of Newton's Law consisting of three diagram representation questions and five critical thinking questions. The pretest issue is given before the learning begins while the posttest is done at the end of the meeting (final).

The application of Physics mobile learning takes into account the indicator aspects of diagram representation and critical thinking. The use of Physics mobile learning in improving the ability of diagram representation in Newton's Law material and Parabolic Motion is adjusted to the indicators and is shown in Table 1. 
Table 1

Matrix of Media

\begin{tabular}{|c|c|c|c|c|}
\hline Indicators & Newton Law I & Newton Law II & Newton Law III & Parabolic Motion \\
\hline \multicolumn{5}{|c|}{ Diagram Representation } \\
\hline $\begin{array}{l}\text { Make sketches } \\
\text { describing the physics } \\
\text { problem }\end{array}$ & $\begin{array}{l}\text { Make sketches a } \\
\text { stone, the stone to be } \\
\text { jumping start }\end{array}$ & $\begin{array}{l}\text { Students sketch the object } \\
\text { in the form a person is } \\
\text { running on certain distance } \\
\text { according to problem }\end{array}$ & $\begin{array}{l}\text { Make sketches a footstool in } \\
\text { the form of a simple diagram } \\
\text { (arrows) }\end{array}$ & $\begin{array}{l}\text { Make sketches a } \\
\text { parabolic motion } \\
\text { on hombobatu } \\
\text { culture. }\end{array}$ \\
\hline $\begin{array}{l}\text { Make an object diagram } \\
\text { or external (motions/ } \\
\text { forces) on observed } \\
\text { object with complete, } \\
\text { clear and relevant to } \\
\text { physical situation. }\end{array}$ & $\begin{array}{l}\text { Provide a force } \\
\text { diagram on stone } \\
\text { object }\end{array}$ & $\begin{array}{l}\text { Provide forces diagram, } \\
\text { acceleration and mass, and } \\
\text { then analyze the } \\
\text { relationship among them. }\end{array}$ & $\begin{array}{l}\text { Provide a forces diagram of } \\
\text { action and reaction }\end{array}$ & $\begin{array}{l}\text { Make acceleration } \\
\text { diagram based on } \\
\text { axes } x \text { and } y .\end{array}$ \\
\hline $\begin{array}{l}\text { Provide an clear and } \\
\text { correct description/ label } \\
\text { on the table }\end{array}$ & $\begin{array}{l}\text { Provide a forces' } \\
\text { name of the stone }\end{array}$ & $\begin{array}{l}\text { Provide the correct symbol } \\
\text { of acceleration, mass and } \\
\text { forces. }\end{array}$ & $\begin{array}{l}\text { Provide name of action and } \\
\text { reaction according to opposite } \\
\text { direction }\end{array}$ & $\begin{array}{l}\text { Provide correct } \\
\text { description on } \\
\text { each vector } \\
\end{array}$ \\
\hline $\begin{array}{l}\text { Using diagram to solve } \\
\text { the physics problem }\end{array}$ & $\begin{array}{l}\text { Find out the solution } \\
\text { on diagram sketch }\end{array}$ & $\begin{array}{l}\text { Apply Law Newton II with } \\
\text { the diagram }\end{array}$ & Apply Law Newton III & $\begin{array}{l}\text { Apply the concept } \\
\text { of parabolic } \\
\text { motion to } \\
\text { HomboBatu }\end{array}$ \\
\hline \multicolumn{5}{|l|}{$\begin{array}{l}\text { Critical Thinking } \\
\end{array}$} \\
\hline $\begin{array}{l}\text { Provide basic } \\
\text { explanation }\end{array}$ & $\begin{array}{l}\text { Provide animation of } \\
\text { HomboBatu that } \\
\text { stand firm. Students } \\
\text { are required to } \\
\text { explain the stone's } \\
\text { inertia }\end{array}$ & $\begin{array}{l}\text { Students explain the basic } \\
\text { explanation on relation } \\
\text { between mass and forces } \\
\text { on a young is running to the } \\
\text { stone }\end{array}$ & $\begin{array}{l}\text { Students explain the basic } \\
\text { explanation on the reason why } \\
\text { a young must rely on stone to } \\
\text { make a jump }\end{array}$ & $\begin{array}{l}\text { Students explain } \\
\text { the motion of a } \\
\text { young when he is } \\
\text { jumping }\end{array}$ \\
\hline Explain arguments & $\begin{array}{l}\text { Students explain their } \\
\text { argument on the } \\
\text { reason why a young } \\
\text { who runs very fast } \\
\text { will be hard to stop }\end{array}$ & $\begin{array}{l}\text { Students are asked their } \\
\text { arguments why a young } \\
\text { who will jump the stone, } \\
\text { they must run fastly / not } \\
\text { slow }\end{array}$ & $\begin{array}{l}\text { Students explain their } \\
\text { argument on landing after a } \\
\text { young has finished jumping }\end{array}$ & $\begin{array}{l}\text { Students write } \\
\text { their opinion on } \\
\text { why parabolic } \\
\text { motion occur on } \\
\text { hombobatu } \\
\text { phenomenon }\end{array}$ \\
\hline $\begin{array}{l}\text { Conduct a logical } \\
\text { thinking }\end{array}$ & $\begin{array}{l}\text { Students analyze the } \\
\text { requirement of } \\
\text { stone's inertia }\end{array}$ & $\begin{array}{l}\text { Students think the forces } \\
\text { and minimum forces that } \\
\text { conducted by a young in } \\
\text { order he able to jump the } \\
\text { stone }\end{array}$ & $\begin{array}{l}\text { Students think the Law } \\
\text { Newton III theoretically on } \\
\text { HomboBatu culture }\end{array}$ & $\begin{array}{l}\text { Analyze the } \\
\text { diagrams of } \\
\text { acceleration and } \\
\text { velocity on } \\
\text { parabolic motion } \\
\end{array}$ \\
\hline Conduct an evaluation & $\begin{array}{l}\text { Students able to } \\
\text { evaluate by } \\
\text { calculating the forces } \\
\text { diagram on stone } \\
\text { pyramid-shaped }\end{array}$ & $\begin{array}{l}\text { Students evaluate on } \\
\text { whether the argument and } \\
\text { forces on young of } \\
\text { hombobatu is relevant to } \\
\text { theory of Law Newton II or } \\
\text { other theories }\end{array}$ & $\begin{array}{l}\text { Students evaluate and } \\
\text { compare the argument to } \\
\text { relevant theories }\end{array}$ & $\begin{array}{l}\text { Conduct an } \\
\text { evaluation on } \\
\text { analysis with } \\
\text { GLBB theory }\end{array}$ \\
\hline $\begin{array}{l}\text { Make decision and } \\
\text { determine the further } \\
\text { steps }\end{array}$ & $\begin{array}{l}\text { Use Law Newton I to } \\
\text { solve the problem on } \\
\text { hombobatu } \\
\text { phenomenon }\end{array}$ & $\begin{array}{l}\text { Students able to correctly } \\
\text { solve the problem when is } \\
\text { given problems relating } \\
\text { hombobatu }\end{array}$ & $\begin{array}{l}\text { Students are faced physic } \\
\text { problem on action and } \\
\text { reaction, and they are able to } \\
\text { solve the problem }\end{array}$ & $\begin{array}{l}\text { Students are able } \\
\text { to solve the GLBB } \\
\text { problems }\end{array}$ \\
\hline
\end{tabular}

\section{Analysis of Data}

Increased Analysis of Representations of Diagrams and Critical Thinking

This increase in pretest and posttest analysis is stated in the Gain standard. The search for Gain standards is as follows with the standard values of gain generated interpreted according to Table 2 . 
Std gain $<g>=\frac{\bar{X}_{\text {Postest }}-\bar{X}_{\text {Pretest }}}{X-\bar{X}_{\text {Pretest }}}$

Table 2

Gain Criteria

\begin{tabular}{ll}
\hline Value $(\mathrm{g})$ & Category \\
$\mathrm{g} \geq 0,7$ & High \\
$0,7>\mathrm{g} \geq 0,3$ & Medium \\
$\mathrm{g}<0,3$ & Low \\
\hline
\end{tabular}

The MANOVA Statistical Test was carried out using SPSS software. The use of the MANOVA test can be done if it fulfills several assumptions, namely normality, and homogeneity. The MANOVA statistical test in this study was using Hotelling's Trace with a significance level of 5\%. The decision criteria taken are $\mathrm{H} 0$ rejected if sig $<0.05$. The research hypothesis in this MANOVA test is as follows:

$\mathrm{H}_{0}$ : There is no difference in increasing the ability of diagram representation and critical thinking between students who are taught using an Android-assisted learning media with PPT media.

$\mathrm{H}_{1}$ : There is a difference in increasing the ability of diagram representation and critical thinking between students who are taught using an Android-assisted learning media with PPT media.

\section{Effect Size Analysis}

Effect size analysis is used to determine how much influence (contribution) learning uses learning media (HomboBatu) assisted by Android in improving the ability of diagram representation and critical thinking of students. This analysis was carried out in two stages, namely the analysis carried out to find the contribution of learning with Android-assisted Hombo Stone media simultaneously to the dependent variable of the ability of diagram representation and critical thinking. Then the analysis was done separately using the results of the pretest and posttest in each class.

Effect size is obtained by calculating Cohen's f value from the transformation of the eta square value in the Test Table between the subject effects, or alternatively Cohen's f value can be calculated using Cohen's equation in the equation below and Cohen's category can be stated in Table 3 .

$$
f=\sqrt{\frac{\eta^{2}}{1-\eta^{2}}}
$$


Table3

Effect Size Criteria

\begin{tabular}{ll}
\hline Effect size & Category \\
0,2 & Small \\
0,5 & Medium \\
0,8 & Large \\
\hline
\end{tabular}

\section{FINDINGS}

In the learning experiment class using RPP with a scientific approach and the Discovery learning model that integrates the HomboBatu culture and Android as a learning medium while in the control class using learning tools commonly used by teachers and not integrating the HomboBatu tradition.Physics mobile learning (PML) is a medium of learning and can be used as a new learning strategy (Cavus\&Uzunboylu, 2009), transformative experience in creating a sense of love to culture, new way of learning Physics, and utilizing technology as a means of delivering material.

Mobile learning physics is designed attractively with Adobe animate and Coreldraw X7, which can be seen in Fig. 4. The media is also given an interactive simulation display shown in Fig. 5 and Fig. 6 so that students can explore the force diagram representation and motion diagrams in HomboBatu. In addition, critical questions and interactive explanations are shown in Fig. 7.

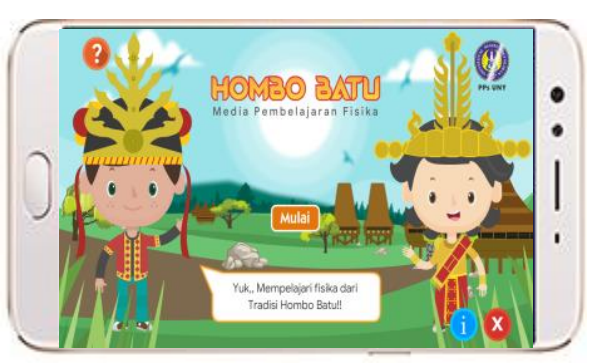

Homepage of Media

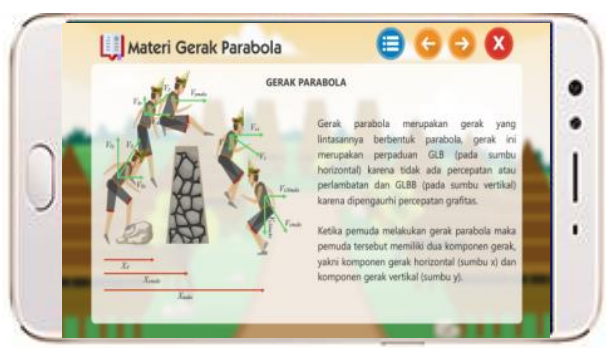

Figure 6

Diagram Representation on Parabolic Motion

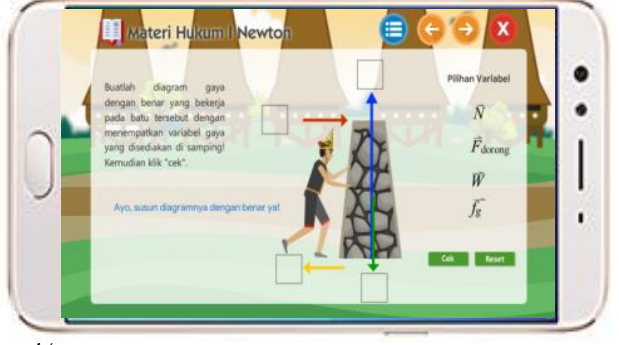

Interactive Simulation

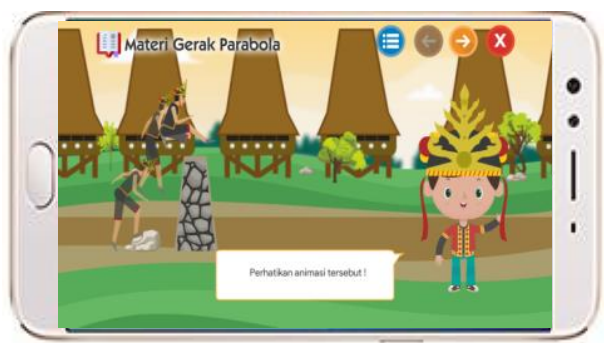

Figure 7

Interactive Questions on the Media 


\section{Result of Improvement of Diagram Representation Ability}

Diagram representation is the ability of students to solve physical problems (Tuminaro\& Edward, 2007; Taufiketal., 2010). The results of this study showed that students analyze and present a problem into a sketch and free body diagram, which way is more effective and facilitates finding solutions for the students (Fredlund et al., 2014). Results of students' ability in diagram representation in control and experimental classis are presented in Fig.8 and Table 4.

Table4

Representation Diagram Ability Test Results

\begin{tabular}{llllll}
\hline \multirow{2}{*}{ Class } & $\mathrm{N}$ & \multicolumn{2}{c}{ Average } & \multirow{2}{*}{ Average Gain Value } & \multirow{2}{*}{ Category } \\
\cline { 3 - 4 } & & Pretest & Posttest & & \\
\hline Control & 32 & 30,89 & 58,08 & 0,39 & Medium \\
\hline Experiment & 22 & 29,61 & 84,29 & 0,78 & Large \\
\hline
\end{tabular}

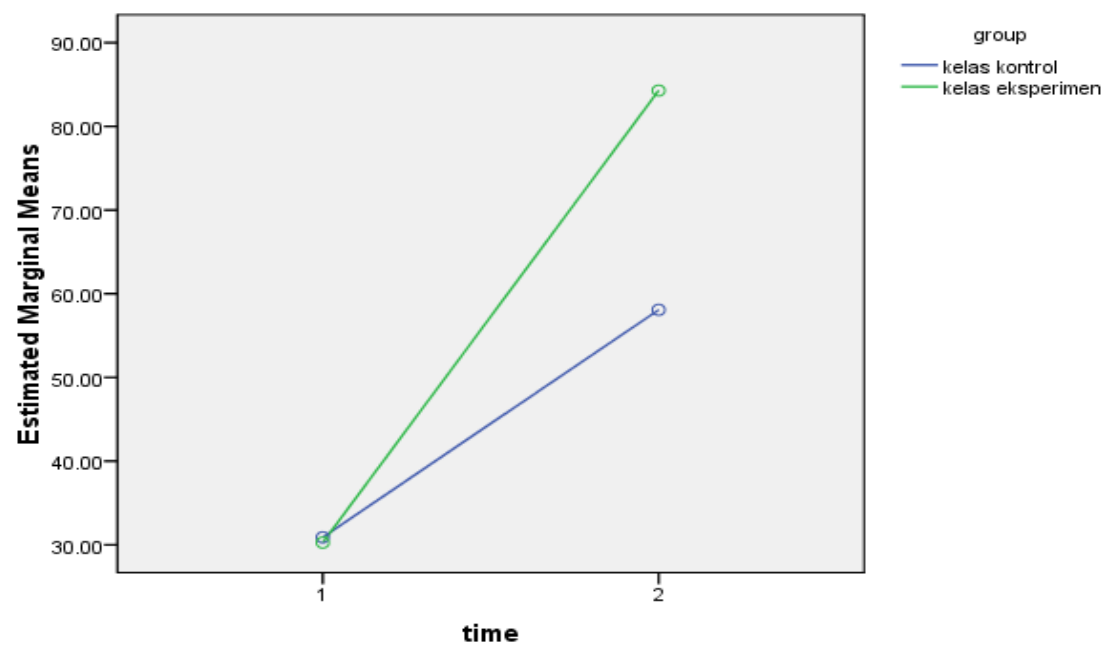

Figure 8

Graph on Improvement Results of Average Score of Students' Ability of Diagram Representation

The students pretest results in control class (number 1) and experiment class (number 2) are in the same starting point (see Fig.8) means that the students' initial ability in the control and experimental class has the same level of ability of diagram representation.

Figure 8 and Table 4 show that both control class and experimental class have an improvement on the ability of diagram representation. But the improvement on ability of diagram representation in experimental class is higher than in control class. This provides the information that learning media (HomboBatu) in learning is more effective in improving the students' ability of diagram representation than is PowerPoint media. This is due to learning media (HomboBatu) Android-assisted better being able to 
visualize the forces diagram of Newton's Law than Powerpoint media, and students who use diagram representation can more optimally solve the Physics problems (Tms\&Sirait, 2016). In addition, the advantage of learning media (HomboBatu) is in providing students with a more concrete learning experience where the students use the media interactively, independently, and collaboratively.

\section{Result of Improvement of Critical Thinking Ability}

Critical thinking is the mental process when we think deeply to find an idea, thought, or assumption with having rational reasons so as to obtain a logical conclusion through several stages such as asking, analyzing, synthesizing, logical thinking, and evaluating (Fisher, 2001; Glesser, 1941; Sternberg, 1985). The learning process with traditionbased Android-assisted media aims to improve students' critical thinking ability through the use of this Android-assisted media. Several treatments are loaded to the media such as basic questions on Newton's Law, animation to allow students analyzing the phenomena and so on. The results of the improvement of critical thinking ability are presented in Fig. 9.

Table 5

Result of Improvement of Critical Thinking Ability

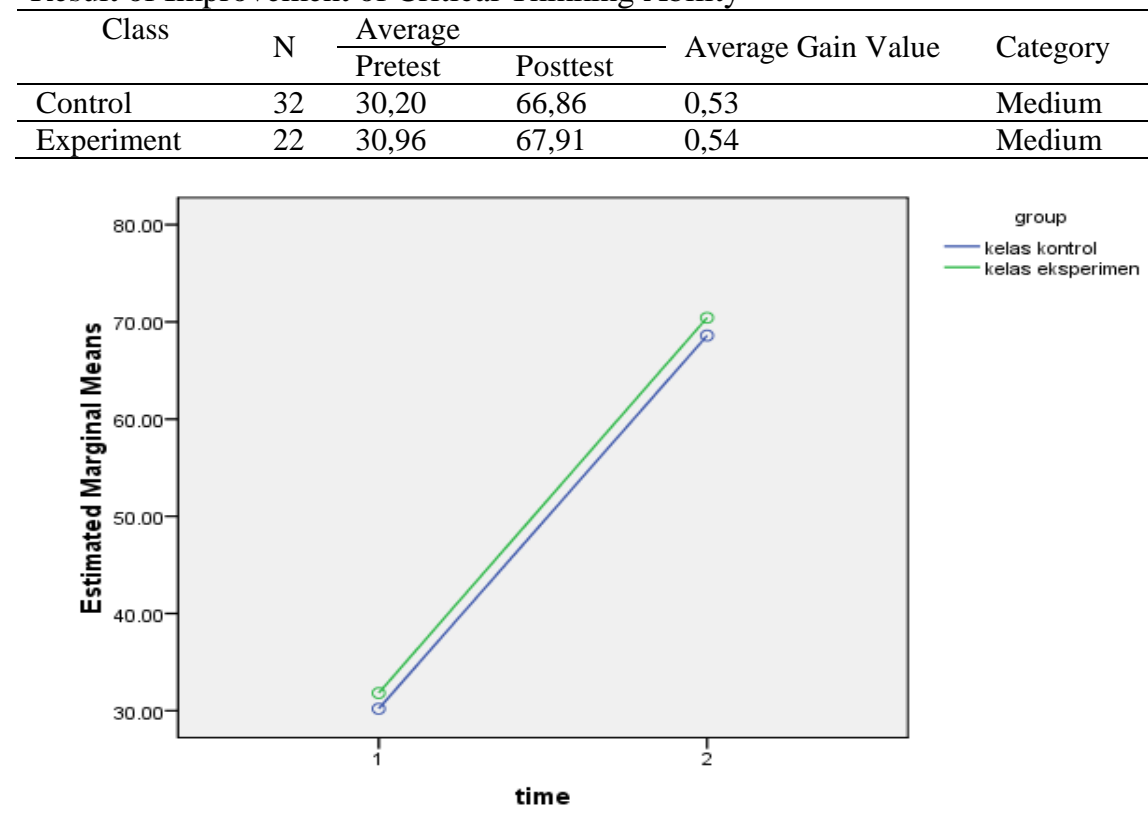

Figure 9

Graph on improvement Results of Critical Thinking Ability

Figure 9 and Table 5 describe the initial critical thinking ability of students seen from the pretest score with the score does not reached the minimum passed criteria scores of schools, both control class and experimental class show the same score of initial ability, 
and there is no significant difference between initial ability of control class and experimental class (Homogeneous). In posttest score, both control class and experimental class have an increase in critical thinking ability as compared with pretest score. The experimental class has higher increase than control class, but differences are not significant. Based on Fig. 6, there is no significant difference in the results of pretest-posttest in control class and experimental class.

The improvement of critical thinking ability belongs to the medium category, because the posttest scores after treatment of the learning with Android learning media have not reached the minimum school criteria. The reason is because the time in learning is not maximized, but the increase of average score of experimental class is higher than that of control class although the differences are not significant. Learning with Android-assisted media with HomboBatuculture theme can therefore improve the students' critical thinking ability. These results are relevant to those of the previous studies (Cavus \& Uzunboylu, 2009; Cobcroft, Towers, Smith, \& Bruns, 2015) which found that Mlearning technology is able to support the students' involvement in creative, collaborative, critical, and communicative learning activities (Cobcroft et al., 2015).

The analysis in this study used the MANOVA test to determine the difference in control classes with conventional learning and the experimental class with learning using an assisted Android Smartphone learning media with regard to the theme of the tradition of HomboBatu. Test the assumptions made are normality and homogeneity test with the results as follows.

Table 6

Normality Test Results

\begin{tabular}{lllll}
\hline & \multirow{2}{*}{ Class } & \multicolumn{4}{l}{ Kolmogorov-Smirnov $^{\mathrm{a}}$} \\
\cline { 3 - 5 } & & Statistic & $\mathrm{df}$ & \multicolumn{1}{l}{ Sig. } \\
\hline Repretation Diagram & Control & .126 & 32 & $.200^{*}$ \\
\cline { 2 - 5 } & Experiment & .117 & 22 & $.200^{*}$ \\
\hline Critical Thinking & Control & .102 & 32 & $.200^{*}$ \\
\cline { 2 - 5 } & Experiment & .113 & 22 & $.200^{*}$ \\
\hline
\end{tabular}

Table 7

Homogeneity Test Results

\begin{tabular}{lllll}
\hline & F & df1 & df2 & Sig. \\
\hline Repretation Diagram & .891 & 1 & 52 & .349 \\
\hline Critical Thinking & 1.987 & 1 & 52 & .165 \\
\hline
\end{tabular}

The result of the normality and homogeneity test shows that the data are normally distributed and homogeneous. The MANOVA test was conducted to see whether there were differences in the control class with conventional learning and the experimental class with learning using Android-assisted learning media with the traditional HomboBatu theme. MANOVA test results with SPSS can be seen in the following table. 
Table 8

Result of Hotelling's Trace

\begin{tabular}{clll}
\hline Effect & sig. & Criteria & Decision \\
\hline Hotelling's Trace & .000 & sig. $<0,05$ & $\mathrm{H}_{0}$ is rejected \\
\hline
\end{tabular}

In the table above, the MANOVA test used is the Hotelling Trace test with an $\mathrm{f}$ value of 21.863 with a sig value of 0.000 smaller than the significance level of 0.05 . Thus, the hypothesis which states that there is a difference between classes taught with Android assisted learning media with the theme HomboBatu and classes taught conventionally (using PPT media), is accepted (Ho rejected). It was concluded that there were significant differences in the ability of diagram representation and critical thinking simultaneous to the control class and the experimental class.

Table 9

Tests of Between-Subjects Effects

\begin{tabular}{llllll}
\hline Source & Dependent Variable & df & Mean Square & F & Sig. \\
\hline \multirow{2}{*}{ Kelas } & Representation diagram & 1 & 9849.411 & 43.803 & .000 \\
\cline { 2 - 6 } & Critical thinking & 1 & 1.154 & .003 & .956 \\
\hline
\end{tabular}

On the Test of Table of Effects subjects, we can see whether there is an influence of the control class and the experimental class on each of the critical thinking ability variables and diagrammatic representations, separately. If the sig value is smaller than 0.05 then there is a significant difference in each variable. From the results above, it can be interpreted that:

a) Significant differences exist in the control class and experimental class in the ability of diagram representation, with a value of sig 0,000 .

b) There is no significant difference between the control and experimental classes on critical thinking skills with a sig value of 0.965 greater than the significance level (0.05). This can be seen in the average value of the control class gain of 0.53 while the experimental class is 0.54 . Only 0.01 is the difference between the two. So, if analyzed at a significance level of 5\%, there is no significant difference between the class with conventional learning (PPT) and the experimental class with Androidassisted media themed HomboBatu. Even if you see it, there are still differences in both of them, even if only a little. This is because learning media is not maximal to train students" critical thinking.

\section{Analysis of Effect Size Effect}

After it is known that learning with Android-assisted Hombo Stone media influences the ability of diagram representation and critical thinking ability, an analysis is conducted to find out how much influence the learning has. The next analysis is done separately based on the dependent variables, namely diagrammatic ability and critical thinking involving the pretest and posttest of each dependent variable, therefore, the multivariate significance seen is that Hotelling's traces can be seen in Table 10. 
Table 10

Analysis of the effect of learning on the ability of diagram representation

\begin{tabular}{llllll}
\hline & Group & $\mathrm{F}$ & Sig. & Partial Eta Squared & Category \\
\hline Control & Hotelling's trace & $1.102 \mathrm{E} 2^{\mathrm{a}}$ & .000 & .679 & Medium \\
\hline Experiment & Hotelling's trace & $2.991 \mathrm{E2}^{\mathrm{a}}$ & .000 & .852 & Large \\
\hline
\end{tabular}

Based on Table 10 it is known that the application of Android-assisted Stone Hombo learning media has an effect on increasing the ability of diagram representation with significance $(p<0.05)$ and with a contribution of an increase of 0.852 in the "high" category and a control class treated with PPT learning media, the effect on the improvement of the ability of Science Literacy in the affective aspect was with significance $(p<0.05)$ of 0.679 with the "medium" category.

Table11

Analysis of the effect of learning on critical thinking abilities

\begin{tabular}{llllll}
\hline & Group & F & Sig. & Partial Eta Squared & Category \\
\hline Experiment & Hotelling's trace & $2.056 \mathrm{E} 2^{\mathrm{a}}$ & .000 & .798 & Medium \\
\hline Control & Hotelling's trace & $1.430 \mathrm{E} 2^{\mathrm{a}}$ & .000 & .733 & Medium \\
\hline
\end{tabular}

Based on Table 11 it is known information that the application of Android-assisted Hombo Stone learning media has an influence on increasing critical thinking skills with significance $(p<0.05)$ with an increase in contribution of 0.798 with the category of "medium" and the control class treated with PPT learning media giving the effect of increasing critical thinking skills with significance $(p<0.05)$ of 0.733 with the "medium" category. Based on this data, it can be concluded that there is no significant difference in the effects of learning with PML learning media assisted by Android smartphones with PPT assisted learning in improving critical thinking skills of students. However, the effect given by the PML learning media is greater, although the magnitude of the influence of the HomboBatu media with PPT media is not too far away (0.798 with 0.733). This is because HomboBatu's learning media has not been maximal to train students' critical thinking and must be revised to be more effective in improving critical thinking skills.

\section{CONCLUSION}

In this study, the effect of Hybrid-PjBL on learning outcomes, creative thinking skills, and increased learning motivation was studied at higher education level. The results of this study indicate that there were significant differences between students who were taught using PjBL learning and the counterparts by conventional learning, both on the parameters of learning outcomes and creative thinking skills. Furthermore, although it did not have any significant difference with the control class, Hybrid-PjBL has had the potential to increase student's learning motivation. The results of this study suggest that Hybrid-PjBL is an alternative form of learning relevant to the demands of the $21 \mathrm{st}$ Century. Assessment of the implementation of Hybrid-PjBL on other parameters needs to be developed in future studies to uncover the positive impact of the model more 
thoroughly. The addition of study duration is also recommended so that the long-term impact of Hybrid-PjBL can be analyzed.

\section{ACKNOWLEDGEMENT}

The authors would like to say thank you to Rector of Universitas Muhammadiyah Malang and the Dean of Faculty of Teacher Training and Education for support in this research (facilities and funding).

\section{REFERENCES}

Afip, L. B. A. (2014). Motivating adult learners using blended learning in higher education institution. International Refereed Research Journal, 5(3), 35-42. doi: $10.1177 / 1046878114534383$

Alhadi, S., \& Saputra, W. N. E. (2017). The relationship between learning motivation and learning outcome of junior high school students in Yogyakarta. In C. S. A. Jabar, L. Purnastuti, M. F. A. Ghani, M. Khairudin, S. Indartono, R. Utari, ... F. Fatimah (Eds.), Proceedings of the 1st Yogyakarta International Conference on Educational Management/Administration and Pedagogy (YICEMAP 2017): Advances in Social Science, Education and Humanities Research (Vol. 66, pp. 138-141). Yogyakarta: Atlantis Press. doi: 10.2991/yicemap-17.2017.23

Ambrosi-randi, P. N., \& Ruži, H. (2010). Motivation and learning strategies in university courses in Italian Language. Metodički Obzori, 10(5), 41-50. Retrieved from https://hrcak.srce.hr/file/98889

Amin, A. M., \& Adiansyah, R. (2018). Lecturers' perception on students' critical thinking skills development and problems faced by students in developing. JPBI (Jurnal Pendidikan Biologi Indonesia), 4(1), 1-10. doi: 10.22219/jpbi.v4i1.5181

Antika, R. N., \& Nawawi, S. (2017). The effect of project based learning model in seminar course to student's creative thinking skills. JPBI (Jurnal Pendidikan Biologi Indonesia), 3(1), 72-79. doi: 10.22219/jpbi.v3i1.3905

Bell, S. (2010). Project-based learning for the 21st century: Skills for the future. The Clearing House: A Journal of Educational Strategies, Issues and Ideas, 83(2), 39-3. doi: 10.1080/00098650903505415

Berns, A., Luis, J., Montes, I., Duarte, M. P., \& Dodero, J. M. (2016). Motivation , students' needs and learning outcomes: A hybrid game-based app for enhanced language learning. SpringerPlus, 5(1), 1305. doi: 10.1186/s40064-016-2971-1

Buku, M. N. I., Mite, Y., Fauzi, A., Widiansyah, A. T., \& Anugerah, D. Y. (2015). Penerapan pembelajaran cooperative script berbasis lesson study sebagai upaya peningkatan keaktifan lisan dan kecakapan sosial mahasiswa SI Pendidikan Biologi matakuliah strategi belajar mengajar. In Proceedings of the 2nd Seminar \& Workshop Nasional Biologi, IPA, dan Pembelajarannya FMIPA UM (pp. 603-606). Malang: Biologi FMIPA UM. 
Chiang, C. L., \& Lee, H. (2016). The effect of project-based learning on learning motivation and problem-solving ability of vocational high school students. International Journal of Information and Education Technology, 6(9), 709-712. doi: 10.7763/IJIET.2016.V6.779

Christou, T. M. (2016). 21 st-century learning, educational reform, and tradition: Conceptualizing professional development in a progressive age. Teacher Learning and Professional Development, 1(1), 61-72. Retrieved from http://journals.sfu.ca/tlpd/index.php/tlpd/article/viewFile/10/11

Crippen, K. J., Wu, C.-Y., Boyer, T., De Torres, T., Korolev, M., \& Brucat, P. J. (2016). A pilot study of project-based learning in general chemistry for engineers. In ASEE Annual Conference and Exposition (Vol. 2016-June). New Orleans, United States: American Society for Engineering Education. Retrieved from https://www.scopus.com/inward/record.uri?eid=2-s2.084983301348\&partnerID=40\&md5=a5829499379cf72fa7b8cee3eff2354c

Dunlosky, J., Rawson, K. A., Marsh, E. J., Nathan, M. J., \& Willingham, D. T. (2013). Improving students' learning with effective learning techniques: Promising directions from cognitive and educational psychology. Psychological Science in the Public Interest, Supplement, 14(1), 4-58. doi: 10.1177/1529100612453266

Ersoy, E., \& Baser, N. e. (2014). The effects of Problem-Based Learning method in higher education on creative thinking. Procedia - Social and Behavioral Sciences, 116, 3494-3498. doi: 10.1016/j.sbspro.2014.01.790

Everaert, P., Opdecam, E., \& Maussen, S. (2017). The relationship between motivation, learning approaches, academic performance and time spent. Accounting Education, 26(1), 78-107. doi: 10.1080/09639284.2016.1274911

Fauzi, A. (2013). Pengaruh kemampuan akademik terhadap keterampilan metakognitif, hasil belajar biologi, dan retensi siswa SMA Kelas X dengan penerapan strategi pembelajaran Cooperative Script di Malang. Universitas Negeri Malang. doi: 10.13140/RG.2.2.24659.99363

Fini, E. H., Awadallah, F., Parast, M. M., \& Abu-Lebdeh, T. (2018). The impact of project-based learning on improving student learning outcomes of sustainability concepts in transportation engineering courses. European Journal of Engineering Education, 43(3), 473-488. doi: 10.1080/03043797.2017.1393045

Flitcroft, D., \& Woods, K. (2018). What does research tell high school teachers about student motivation for test performance? Pastoral Care in Education, 36(2), 112-125. doi: $10.1080 / 02643944.2018 .1453858$

Genlott, A. A., \& Grönlund, Å. (2013). Improving literacy skills through learning reading by writing: The iWTR method presented and tested. Computers and Education, 67, 98-104. doi: 10.1016/j.compedu.2013.03.007

Gregory, E., Hardiman, M., Yarmolinskaya, J., Rinne, L., \& Limb, C. (2013). Building 
creative thinking in the classroom: From research to practice. International Journal of Educational Research, 62, 43-50. doi: 10.1016/j.ijer.2013.06.003

Hamoush, S., Fini, E. H., Parast, M. M., \& Sarin, S. (2011). The effect of project-based learning $(P B L)$ on improving student learning outcomes in transportation engineering. ASEE Conference Proceeding. Vancouver: American Society for Engineering Education. Retrieved from https://www.asee.org/public/conferences/1/papers/564/download.

Hoferichter, F., Raufelder, D., \& Eid, M. (2015). Socio-motivational moderators-two sides of the same coin? Testing the potential buffering role of socio-motivational relationships on achievement drive and test anxiety among German and Canadian secondary school students. Frontiers in Psychology, 6(OCT), 1-13. doi: 10.3389/fpsyg.2015.01675

Hoffman, B. (2009). 5 pitfalls to understanding people's motives: An educational psychologist reveals why it can be so tricky to interpret the behavior of others - and ourselves. Retrieved from https://www.elsevier.com/connect/5-pitfalls-to-understandingpeoples-motives

Husamah, H. (2015a). Blended project based learning: Metacognitive awareness of biology education new students. Journal of Education and Learning, 9(4), 274-281. doi: 10.11591/edulearn.v9.i4.2121

Husamah, H. (2015b). Thinking skills for environmental sustainability perspective of new students of biology education department through blended project based learning model. Jurnal Pendidikan IPA Indonesia, 4(2), 110-119. doi: 10.15294/jpii.v4i2.3878

Husamah, H., \& Pantiwati, Y. (2014). Cooperative learning STAD-PJBL: Motivation, thinking skills, and learning outcomes of biology department students. International Journal of Education Learning and Development, 2(1), 77-94.

Isabekov, A., \& Sadyrova, G. (2018). Project-based learning to develop creative abilities in students. In J. Drummer, G. Hakimov, M. Joldoshov, T. Köhler, \& S. Udartseva (Eds.), Vocational Teacher Education in Central Asia: Developing Skills and Facilitating Success (pp. 43-49). Cham: Springer International Publishing. doi: 10.1007/978-3-319-73093-6_4

Jerome, C., Lee, J. A.-C., \& Ting, S.-H. (2017). What students really need : instructional strategies that enhance higher order thinking skills ( hots ) among unimas undergraduates. International Journal of Business and Society, 18(4), 661-668. Retrieved from http://www.ijbs.unimas.my/images/repository/pdf/Vol18-s4-paper2.pdf

Joibari, A., \& Mohammadtaheri, N. (2011). The study of relation between emotional intelligence and students' academic achievement of High schools in Tehran city. In Z. Bekirogullari (Ed.), Procedia - Social and Behavioral Sciences (Vol. 29, pp. 13341341). Elsevier B.V. doi: 10.1016/j.sbspro.2011.11.371

Kaur, S. (2013). HRM in 21 st Century: Challenges of future. International Journal of 
Emerging Research in Management \&Technology, 9359(26), 2278-9359. Retrieved from https://www.ermt.net/docs/papers/Volume_2/issue_6_June2013/V2N6-137.pdf

Keller, J. (1984). The use of the ARCS model of motivation in teacher training. In K. Shaw \& A. J. Trott (Eds.), Aspects of Educational Technology Volume XVII. London: Kogan Page.

Keller, J. (1987). Development of the ARCS model of instructional design. Journal of Instructional Development, 10(3), 2-10. doi: 10.1002/pfi.4160260802

Kiviniemi, M. T. (2014). Effects of a blended learning approach on student outcomes in a graduate-level public health course. BMC Medical Education, 14(1), 1-7. doi: $10.1186 / 1472-6920-14-47$

Kokotsaki, D., Menzies, V., \& Wiggins, A. (2016). Project-based learning: A review of the literature. Improving Schools, 19(3), 267-277. doi: 10.1177/1365480216659733

Krishnan, S., Gabb, R., \& Vale, C. (2011). Learning cultures of problem-based learning teams. Australasian Journal of Engineering Education, 17(2), 67-78. doi: 10.1080/22054952.2011.11464057org/10.1080/22054952.2011.11464057

Kudryashova, A., Gorbatov, T., Rybushkina, S., \& Ivanova, E. (2016). Teacher's roles to facilitate active learning. Mediterranean Journal of Social Sciences, 7(1), 460-466. doi: 10.5901/mjss.2016.v7n1p460

Larson, L. C., \& Miller, T. N. (2011). 21st century skills: Prepare students for the future. Kappa Delta Pi Record, 47(3), 121-123. doi: 10.1080/00228958.2011.10516575

Lee, S., \& Carpenter, R. (2015). Creative thinking for 21 st century composing practices: Creativity pedagogies across disciplines. Across the Disciplines, 12(4), 1-24. Retrieved from https://wac.colostate.edu/atd/performing_arts/lee_carpenter2015.cfm

Lin, L. (2015). Exploring collaborative learning: Theoretical and conceptual perspectives. In Investigating Chinese HE EFL Classrooms: Using Collaborative Learning to Enhance Learning (pp. 11-28). Verlag Berlin Heidelberg: Springer. doi: 10.1007/978-3-662-44503-7_2

Lin, Y.-S. (2011). Fostering creativity through education - A conceptual framework of creative pedagogy. Creative Education, 02(03), 149-155. doi: 10.4236/ce.2011.23021

López-Pérez, M. V., Pérez-López, M. C., \& Rodríguez-Ariza, L. (2011). Blended learning in higher education: Students' perceptions and their relation to outcomes. Computers and Education, 56(3), 818-826. doi: 10.1016/j.compedu.2010.10.023

Magsino, R. M. (2014). Enhancing higher order thinking skills in a marine biology class through Problem-Based Learning. Asia Pacific Journal of Multidisciplinary Research, 2(5), 1-6. Retrieved from http://www.apjmr.com/wp-content/uploads/2014/09/APJMR2014-2-116.pdf

Marzano, R. J. (2001). Designing a new taxonomy of educational objectives: Experts in 
assessment. Thousand Oaks, CA: Corwin Press, Inc. Retrieved from https://eric.ed.gov/?id=ED447161

Masino, S., \& Niño-Zarazúa, M. (2016). What works to improve the quality of student learning in developing countries? International Journal of Educational Development, 48, 53-65. doi: 10.1016/j.ijedudev.2015.11.012

Mcfarlane, D. A. (2013). Understanding the challenges of science education in the 21st century: New opportunities for scientific literacy. International Letters of Social and Humanistic Sciences, 4, 35-44. doi: 10.18052/www.scipress.com/ILSHS.4.35

Mohzan, M. A. M., Hassan, N., \& Halil, N. A. (2013). The influence of emotional intelligence on academic achievement. In Procedia - Social and Behavioral Sciences (Vol. 90, pp. 303-312). Elsevier B.V. doi: 10.1016/j.sbspro.2013.07.095

Movahedzadeh, F., Patwell, R., Rieker, J. E., \& Gonzalez, T. (2012). Project-based learning to promote effective learning in biotechnology courses. Education Research International, 2012, 1-8. doi: 10.1155/2012/536024

Nagappan, R. (2010). Teaching thinking skills at institutions of higher learning: Lessons learned. Pertanika Journal of Social Science and Humanities, 18, 1-14. Retrieved from http://www.pertanika.upm.edu.my/PertanikaPAPERS/JSSHVol.18(S)Dec.2010/07Pg1 14.pdf

Napier, N. P., Dekhane, S., \& Smith, S. (2011). Transitioning to blended learning: Understanding student and faculty perceptions. Journal of Asynchronous Learning Network, 15(1), 20-32. doi: 10.1177/009155218701500207

Özdas, F., \& Batdi, V. (2017). A Thematic-based meta analytic study regarding the effect of creativity on academic success and learning retention. Journal of Education and Training Studies, 5(3), 53. doi: 10.11114/jets.v5i3.2043

Prasertcharoensuk, T., Somprach, K., \& Ngang, T. K. (2015). Influence of teacher competency factors and students' life skills on learning achievement. In Procedia Social and Behavioral Sciences (Vol. 186, pp. 566-572). Elsevier B.V. doi: 10.1016/j.sbspro.2015.04.021

Ramadani, S. D., Fauzi, A., Sukmawati, I., \& Corebima, A. D. (2015). Perbandingan potensi strategi pembelajaran cooperative script dan reciprocal teaching dalam memberdayakan keterampilan metakognitif, hasil belajar Biologi, dan retensi siswa SMA. In Proceedings of the 2nd Seminar \& Workshop Nasional Biologi, IPA, dan Pembelajarannya FMIPA UM (pp. 655-661). Malang: Biologi FMIPA UM.

Rambely, A. S., Ahmad, R. R., Majid, N., M-Suradi, N. R., Din, U. K. S., A-Rahman, I., ... Abu-Hanifah, S. (2013). Project-based activity: Root of research and creative thinking. International Education Studies, 6(6), 66-71. doi: 10.5539/ies.v6n6p8

Ramdiah, S., Abidinsyah, H., \& Mayasari, R. (2018). Problem-based learning: Generates higher-order thinking skills of tenth graders in ecosystem concept. JPBI (Jurnal Pendidikan Biologi Indonesia), 4(1), 29-34. doi: 10.22219/jpbi.v4i1.5490 
Ritter, S. M., \& Mostert, N. (2016). Enhancement of creative thinking skills using a cognitive-based creativity training. Journal of Cognitive Enhancement, 243-253. doi: $10.1007 / \mathrm{s} 41465-016-0002-3$

Shaheen, R. (2010). Creativity and education. Creative Education, 1(3), 166-169. doi: 10.4236/ce.2010.13026

Shea, J., Joaquin, M. E., \& Gorzycki, M. (2015). Hybrid course design: Promoting student engagement and success. Journal of Public Affairs Education, 21(4), 539-556. doi: $10.1080 / 15236803.2015 .12002219$

Silva, E. (2009). Measuring skills for 21st-centrury learning. Phi Delta Kappan, 90(9), 630-634. doi: 10.1177/003172170909000905

Sogunro, O. A. (2014). Motivating Factors for Adult Learners in Higher Education. International Journal of Higher Education, 4(1), 22-37. doi: 10.5430/ijhe.v4n1p22

Sukmawati, I., Ramadani, S. D., Fauzi, A., \& Corebima, A. D. (2015). Perbedaan pemberdayaan retensi antara siswa SMA akademik rendah dan tinggi melalui pembelajaran cooperative script dalam pembelajaran biologi. In Proceedings of the 2 nd Seminar \& Workshop Nasional Biologi, IPA, dan Pembelajarannya FMIPA UM (pp. 662-667). Malang: Biologi FMIPA UM.

Taniguchi, Y., Gao, Y., Kojima, K., \& Konomi, S. (2018). Evaluating learning stylebased grouping strategies in real-world collaborative learning environment. In $\mathrm{S}$. Konomi \& N. Streitz (Eds.), Distributed, Ambient and Pervasive Interactions: Technologies and Contexts - 6th International Conference, DAPI 2018, Held as Part of HCI International 2018 (Vol. 10922 LNCS, pp. 227-239). Springer Verlag. doi: 10.1007/978-3-319-91131-1_18

Taurina, Z. (2015). Students' motivation and learning outcomes: Significant factors in internal study quality assurance system. International Journal for Cross-Disciplinary Subjects in Education, 5(4), 2625-2630. Retrieved from https://infonomicssociety.org/wp-content/uploads/ijcdse/published-papers/special-issue-volume-52015/Students-Motivation-and-Learning-Outcomes-Significant-Factors-in-InternalStudy-Quality-Assurance-System.pdf

Thompson, T. (2017). Teaching creativity through inquiry science. Gifted Child Today, 40(1), 29-42. doi: 10.1177/1076217516675863

Tofade, T., Elsner, J., \& Haines, S. T. (2013). Best practice strategies for effective use of questions as a teaching tool. American Journal of Pharmaceutical Education, 77(7), 1-9. doi: 10.5688/ajpe777155

Trilling, B., \& Fadel, C. (2009). 21st century skills: Learning for life in our times. San Francisco: Jossey-Bass. Retrieved from http://psycnet.apa.org/record/2009-18745-000

Vaughan, N. (2014). Student engagement and blended learning: Making the sssessment connection. Education Sciences, 4(4), 247-264. doi: 10.3390/educsci4040247 
Vero, E., \& Puka, E. (2017). The importance of motivation in an educational environment. Formazione \& Insegnamento $X V, 15(1)$, 57-66. Retrieved from http://ojs.pensamultimedia.it/index.php/siref/article/viewFile/2164/1973

Widiansyah, A. T., Indriwati, S. E., Munzil, M., \& Fauzi, A. (2018). I-invertebrata as an android-based learning media for molluscs, arthropods, and echinoderms identification and its influence on students' motivation. JPBI (Jurnal Pendidikan Biologi Indonesia), 4(1), 43-52. doi: 10.22219/jpbi.v4i1.5476 43

Wilson, K. (2016). Critical reading, critical thinking: Delicate scaffolding in English for Academic Purposes (EAP). Thinking Skills and Creativity, 22, 256-265. doi: 10.1016/j.tsc.2016.10.002

Wood, C., Rowell, L., \& Hong, E. (2013). Academic motivation: Concepts, strategies, and counseling approaches. Professional School Counseling, 6(3), 158-171. doi: $10.1111 /$ cdev. 12036

Zouganeli, E., Tyssø, V., Feng, B., Arnesen, K., \& Kapetanovic, N. (2014). Projectbased learning in programming classes - The effect of open project scope on student motivation and learning outcome. In IFAC Proceedings Volumes (IFAC-PapersOnline) (Vol. 19, pp. 12232-12236). Cape Town: IFAC. doi: 10.3182/20140824-6-ZA1003.02412 